DEVELOPING RESEARCH AND PRACTICE

\title{
Beyond usability: designing effective technology implementation systems to promote patient safety
}

\author{
B-T Karsh
}

Qual Saf Health Care 2004;13:388-394. doi: 10.1136/qshc.2004.010322

Evidence is emerging that certain technologies such as computerized provider order entry may reduce the likelihood of patient harm. However, many technologies that should reduce medical errors have been abandoned because of problems with their design, their impact on workflow, and general dissatisfaction with them by end users. Patient safety researchers have therefore looked to human factors engineering for guidance on how to design technologies to be usable (easy to use) and useful (improving job performance, efficiency, and/or quality). While this is a necessary step towards improving the likelihood of end user satisfaction, it is still not sufficient. Human factors engineering research has shown that the manner in which technologies are implemented also needs to be designed carefully if benefits are to be realized. This paper reviews the theoretical knowledge on what leads to successful technology implementation and how this can be translated into specifically designed processes for successful technology change. The literature on diffusion of innovations, technology acceptance, organisational justice, participative decision making, and organisational change is reviewed and strategies for promoting successful implementation are provided. Given the rapid and ever increasing pace of technology implementation in health care, it is critical for the science of technology implementation to be understood and incorporated into efforts to improve patient safety.

Correspondence to: Dr B-T Karsh, Department of Industrial Engineering, University of WisconsinMadison, 1513 University Avenue, Room 387, Madison, WI 53706, USA; bkarsh@engr.wisc.edu

Accepted for publication 3 July 2004
$\mathrm{T}$ here is a growing recognition among those concerned with quality of care and patient safety that technology, especially information technology, may hold the key to improvements. ${ }^{1-8}$ These new technologies have the potential to improve all aspects of healthcare delivery from diagnosis and treatment to administration and billing. The pace of new technology implementation in healthcare delivery has been accelerating over the years, and there is good reason to believe that this will not change in the near future because of pressures from government, purchasing groups, and consumers. ${ }^{4-9}$ This pressure seems to be having an effect. Recent estimates suggest that up to $40 \%$ of US hospitals are planning to implement electronic order entry within the next 5 years $^{10}$ and a 2002 ISMP survey found that $50 \%$ of the responding hospitals were considering implementing bar coding technology. ${ }^{11}$ With the pace of technology implementations likely to accelerate, it is imperative that healthcare delivery organizations understand how to maximize the potential benefits of patient safety technologies.

Human factors engineering science-which includes the study of technology design and evaluation-has shown that, for technology to be used effectively (that is, in the intended manner), it must be usable (that is, easy to use) by the potential end users. ${ }^{12}{ }^{13}$ Among patient safety scientists and practitioners, technology usability is becoming accepted as a necessary component of design to ensure that new technologies are used effectively; this is clear from the number of recent publications on the topic in the healthcare literature. ${ }^{14-19}$

While there is clear evidence that, for technologies to be used effectively they must be designed to be usable (that is, easy to use) and useful (that is, will improve job performance, efficiency, and/or quality), ${ }^{20-23}$ the evidence is also clear that design does not end once usability and usefulness are addressed. ${ }^{24-26}$ The way that technology is implemented into an organisation must also be designed properly to increase the probability of effective use. Studies of technology adoption and acceptance in health care are beginning to appear in the literature, which is a sign that the importance of implementation is becoming more recognised. ${ }^{27-36}$ The purpose of this paper is to present the argument that the design of technology implementation-separate from usability considerations-may independently determine the extent to which end users accept and use new technologies such as those designed to improve patient safety. ${ }^{25}{ }^{37-42}$

\section{UNDERSTANDING THE IMPACT OF NEW TECHNOLOGY ON END USERS}

The effects of new technology on users, the organisation, and work processes are dependent on many factors. For example, new technology will often change how jobs and tasks are accomplished, the extent of division of labour, the span of organisational control, and the degree of coordination. ${ }^{44}$ The changes themselves may be for the better, but they are changes nonetheless. Because so much typically does change with the introduction of new technology, employee resistance is likely which may reduce or prevent the effective use of the technology.

Resistance to change is a complex phenomenon and several theories have been proposed to explain it. Equity implementation theory ${ }^{45}$ suggests that users assess changes in terms of gain 
or loss in equity status, compare their relative outcomes with that of the organisation, and compare their relative outcomes with other users. Changes perceived as being favourable-for example, if the administration of bar coded medication results in faster and safer medication administration-will be accepted, and changes viewed as unfavourable-for example, if medication administration takes longer-will be resisted.

Attribution theory has also been used to explain end user resistance to new technology. ${ }^{46}$ The model posits that the introduction of new technology, the external environment, and internal interpersonal influences combine with previous success or failure with implementing new technologies to influence causal attributions. The attributions can influence expectations of what will happen during and after the implementation. This then may affect affective and behavioural reactions to the use of the new technology. In fact, there is empirical support that previous negative experiences with information technology can lead to the rejection of new systems ${ }^{47}$ Taken together, the two theories posit that, if an implementation is designed such that potential end users (nurses, physicians, pharmacists, etc) believe that (a) their jobs will change for the worse, (b) their work will become worse relative to another group, (c) the organisation is benefiting from the new technology at their expense, or (d) this change will be as bad as previous changes, there is an increased likelihood that end users will reject the new technology. It is therefore clear that, even if a technology is user friendly, the design of the implementation will be at least as critical in determining end user acceptance and effective use.

\section{THE SCIENCE OF DESIGNING NEW TECHNOLOGY IMPLEMENTATION}

Several decades of research have helped to provide empirical evidence showing what types of design practices help to create technology implementation processes that are likely to promote end user acceptance and effective use of new technologies. Major contributions come from the studies of technology acceptance, technology implementation, diffusion of innovations, organisational justice, participative decision making and technology/organisational change. Key research from these areas will be discussed to make the case that the science of implementation does, in fact, exist and should be used to design technology implementation processes.

The questions that need to be addressed first are: (1) why focus on the notion of "design" and (2) what does it mean to design a technology implementation? The first question is central to the goal of patient safety and reflects decades of work in safety outside health care. There are two main ways to approach safety goals-reactive approaches and proactive approaches. The reactive approaches are certainly most well known in health care, as was seen in a recent debate on whether to focus patient safety efforts on errors or injuries. ${ }^{48}$ Both approaches are primarily reactive in that data on errors or injuries must first be collected so that prevention efforts can be implemented. An entirely different approach is to be proactive and not wait for either errors or injuries, but rather to focus on making sure that existing systems are designed to prevent errors or injuries from happening in the first place. There is a well known science to such design which is known as human factors engineering. ${ }^{50}$ As far as the second question is concerned, design is typically thought of in terms of products (such as software, IV pumps, surgical tools) but also applies to processes. The methods by which technologies are implemented into organisations are all processes and they will either be designed well or poorly. The review of the key literature contributing to our understanding of how to design an implementation will show that process design principles and guidelines exist which can be followed to reduce the likelihood of technology rejection and increase the likelihood of acceptance.

\section{WHAT PREDICTS WHETHER PEOPLE INTEND TO USE NEW TECHNOLOGIES?}

For several reasons the literature on how to design technology implementation processes appropriately has mostly focused on one of two outcomes: (a) satisfaction with technology and (b) willingness to use the technology which is typically discussed as "technology acceptance" and/ or "behavioural intention to use". ${ }^{20-2251}$ The former is typically used when the technology being studied is mandatory-that is, end users do not have a choice in using the technology. This is the typical situation in health care, as in the case where a hospital replaces its IV pumps with Smart IV pumps. Willingness to use the technology is used most often when the technology is voluntary-that is, users have a choice to use it (for example, physicians can choose to use electronic order entry or to hand write prescriptions). These two measures are used more often than measures of actual use because it is much simpler to measure satisfaction, acceptance, or intention to use-which can be measured with validated survey items-than it is to measure actual use. Strong cases have been made in theories such as the theory of reasoned action, the transtheoretical model, diffusion of innovations, and the theory of planned behaviour that the best predictor of actual behaviour is behavioural intentions, ${ }^{52-56}$ suggesting that the more simple to measure construct of behavioural intention or acceptance might be a reasonable proxy measure of actual use in voluntary environments. In environments where the use of a particular technology is mandatory-for example, the replacement of paper records with electronic medical records-satisfaction with technology is thought to be related to performance with the technology. Because similar variables have been found to predict both technology acceptance with voluntary technologies and technology satisfaction with mandatory technologies (although the strength of the relationships between variables does differ in the two environments ${ }^{57}$ ), the terms "acceptance" and "satisfaction" will be used interchangeably for the remainder of the paper. An important question to answer for understanding how to design technology implementation processes is therefore-what affects technology acceptance or satisfaction? These factors should illuminate design criteria for implementation processes.

\section{Organisational factors}

Organisational factors that have been found to predict end user technology acceptance focus on decisions made by management related to how a new technology will be implemented. ${ }^{32}$ One such factor is how well the new technology will be integrated with existing technologies, workflow, the environment, and other social systems. ${ }^{58} 59$ For example, if a hospital plans to implement electronic order entry, there will be integration issues related to medical records, pharmacy information systems, current methods of ordering and dispensing medications, space for computer terminals, lighting, and workflow. Technical system changes cannot be designed in isolation from the subsystems involving humans, and technical systems must fit within the constraints of the environment. What that means is that, if a new technology does not work well with other existing technologies end users must use, is not usable in the existing environment (for example, lack of space or lighting causes glare), or does not positively impact workflow, resistance to the new technology is likely.

Management commitment to the new technology and the implementation process has also been found to be an important predictor of the success of the change. ${ }^{26}$ This 
commitment needs to be shown through specific actions. For example, the reason(s) for the new technology should be made clear in order to reduce uncertainty about the necessity of the new technology and to foster positive attitudes toward the technology.$^{60}$ Clarity in the reasons for the new technology also facilitates the development of measures of success as well as accountability for the change.

Another indicator of management commitment and good planning is the presence of a structured program for implementation. ${ }^{265860}$ A structured program might take a variety of forms including a multidisciplinary transition team, clear direction for end users and managers as to where to go for help, and structured communication networks between supervisors and workers to deal with the new technology. A well designed structure indicates that the organization is ready for the change to the new technology, which may serve to reduce the likelihood of resistance. ${ }^{61}$

Perhaps the two most often studied and empirically supported organizational factors that can promote the acceptance of technology by the end users are training and participation. The science of training is well established. ${ }^{62-64}$ Not surprisingly, well designed training programs have been shown to promote end user acceptance of technology. ${ }^{23} 6566$ The key is to design the training program according to the scientific evidence. Well designed training not only transfers knowledge and skills about the technology, but it can also bring understanding of the technology through education and can create feelings of involvement in decisions. ${ }^{67}$ In addition, training can lead to several other important variables for the acceptance of technology including selfefficacy $^{65} 68$ and intrinsic motivation. ${ }^{23} 66$

Just as well designed training can improve the likelihood that the technology will be accepted, appropriately designed end user participation in the implementation of new technology can also increase the likelihood of acceptance. ${ }^{25} 446970$ There are several possible reasons why end user participation in new technology decisions improves acceptance. Empirical evidence suggests a link between participation and improved performance, ${ }^{71-73}$ job satisfaction, ${ }^{74}$ role strain, ${ }^{75}$ commitment, ${ }^{74}$ and reduced stress, ${ }^{76}$ although the strength of evidence and reasons for the findings of at least the first two have been widely debated. ${ }^{77}$ Those relationships might suggest that participation improves the likelihood of technology acceptance by improving end user job satisfaction and performance at a time when both are likely to be suffering, and also possibly because the stress caused by the change is buffered.

Underlying these empirical findings are theoretical reasons that might explain the positive effects of participation. The two dominant theories for the effects of participation on outcomes are the motivational and cognitive models. ${ }^{78}{ }^{79}$ The motivational model suggests that participation improves commitment, trust, and control while reducing resistance to change and anxiety, therefore having a motivational effect on employees. Such would be the case if nurses and pharmacists were involved in designing and implementing a point of care bar code system and, because they felt management trusted them, they became motivated to use the product. On the other hand, the cognitive model proposes that the positive effects of participation are due to increases in information and knowledge which reduce uncertainty. An example of this would be if the nurses and pharmacists gained valuable information about the technology through their participation and were thus less anxious about the proposed change. While there is debate as to which of the theories explains the impact of participatory processes, both make a clear case as to why employee participation in the implementation of new technology should increase acceptance. In addition, participation leads to increased social interaction which may facilitate social support. Social support alone may have direct effects in reducing stress and improving health, ${ }^{80} 81$ although the evidence is not consistent.

Research that has looked specifically at the role of participation in the implementation of new technologies has found positive outcomes. Empirical evidence exists for participation leading to higher levels of acceptance of the new technologies and lower levels of dissatisfaction and stress, ${ }^{76}$ as well ratings that newer systems were better than older ones, that implementation schedules were more reasonable, and that the attitudes of the implementation team and managers towards the implementation were more favourable. ${ }^{82}$ While other studies continue to show results supportive of the positive impact of end user participation on technology acceptance, ${ }^{83} 84$ negative results have also been found. ${ }^{85}$ Negative findings may be due to participation not being useful in all situations or to specific studies being impacted by the many well known limitations and potential problems with participation..$^{37} 8087$

Organisational justice-another organisational factor important for new technology implementation-is broadly defined as the fair treatment of employees. It is often described as being composed of distributive, procedural, and interactional justice. Distributive justice perceptions are based on the distribution of outcomes of decisions, ${ }^{88}$ procedural justice focuses on the fairness of how decisions are made, ${ }^{89} 90$ and interactional justice refers to how employees in an organization treat those below them or subject to their authority. Processes that show fairness in decision making include (1) following consistent procedures, (2) using non-biased decision making, (3) using accurate information, (4) having the opportunity to correct mistakes, (5) having all interested parties represented, (6) using ethical criteria, and (7) giving advanced notice. ${ }^{91}{ }^{92}$ Cobb et al ${ }^{90}$ added giving the employees a voice in the establishment of ground rules or procedures to be used in the change process, which is the same as participation. Procedural concerns may be more significant in the long term as employees consider how to maintain or prevent outcome patterns which are perceived as favourable or unfavourable. ${ }^{93}$ It is natural that issues of justice arise in any change process since change may cause stress and loss. ${ }^{90}$

When workers see themselves being treated fairly, they may develop attitudes and behaviours necessary for successful change even under conditions of adversity and loss. ${ }^{90}$ Addressing justice issues is therefore one key to successfully implementing organisational change. ${ }^{94}{ }^{95}$ Empirical evidence supports the importance of justice perceptions for accepting or being satisfied with new technology ${ }^{96}$ as well as for accepting or being satisfied with other types of changes such as organisational downsizing, job classification restructuring, facility relocation, and technology interface development. ${ }^{92} 93$ 97-99

\section{Technology factors}

The technological characteristics most often studied and linked to technology acceptance are response time, flexibility, breakdowns or crashes, usability or ease of use, and usefulness. The last two have been the most thoroughly researched because they are both central to the technology acceptance model (TAM), ${ }^{20-23} 511^{100-104}$ the most thoroughly studied theory of technology acceptance. The concept of usefulness is not only determined by technological design but also by selection which is a management decision. Nevertheless, it is being categorized here as a technology factor because end user perceptions of usefulness are tied to the performance of the technology.

Ease of use and usefulness of technology are the key determinants of acceptance according to the TAM. ${ }^{100}$ As 
Table 1 Implementation design principles and predictors of technology acceptance

\begin{tabular}{|c|c|c|c|c|c|c|c|c|}
\hline $\begin{array}{l}\text { Variables affecting } \\
\text { success of } \\
\text { implementation }\end{array}$ & $\begin{array}{l}\text { Top management } \\
\text { commitment }\end{array}$ & $\begin{array}{l}\text { Responsibility/ } \\
\text { accountability }\end{array}$ & $\begin{array}{l}\text { Structured } \\
\text { program }\end{array}$ & Training & Pilot testing & $\begin{array}{l}\text { Communication } \\
\text { and feedback }\end{array}$ & Simulation & $\begin{array}{l}\text { End user } \\
\text { participation }\end{array}$ \\
\hline $\begin{array}{l}\text { Uncertainty about } \\
\text { change }\end{array}$ & $x$ & $x$ & $x$ & $x$ & $x$ & $x$ & $x$ & $x$ \\
\hline Work changes & $\times$ & & $x$ & $x$ & $x$ & $x$ & $x$ & $\times$ \\
\hline Resistance to change & $\times$ & & $x$ & $x$ & $x$ & $x$ & $x$ & $\times$ \\
\hline Lack of control & $\times$ & $x$ & $x$ & $x$ & $x$ & $x$ & $x$ & $\times$ \\
\hline Ease of use & $\times$ & & & $x$ & $x$ & $x$ & $\times$ & $\times$ \\
\hline Usefulness & $\times$ & & $\times$ & $x$ & $x$ & $x$ & $x$ & $\times$ \\
\hline Subjective norms & $\times$ & $x$ & $x$ & & $x$ & $x$ & & $\times$ \\
\hline Self-efficacy & $\times$ & & & $x$ & $x$ & $x$ & $x$ & $\times$ \\
\hline Integration & $\times$ & & $x$ & & $x$ & $x$ & & $\times$ \\
\hline Justice & $\times$ & $\times$ & $\times$ & $x$ & $\times$ & $\times$ & $\times$ & $\times$ \\
\hline Readiness for change & $\times$ & $x$ & $x$ & $x$ & $x$ & $x$ & $x$ & $x$ \\
\hline Technology design & $\times$ & $x$ & $x$ & $x$ & $x$ & $x$ & $x$ & $x$ \\
\hline
\end{tabular}

characterised within the TAM, usefulness is a measure of the indirect impact of technology on acceptance because it is an indication of the extent to which users believe a technology will help them perform their job better. If a physician thought that a computerised decision support system would help him or her to avoid incorrect orders, then the technology might be perceived as useful. Ease of use, or usability, was proposed to impact acceptance by improving end user self-efficacy-that is, for example, to the extent that a point of care bar coding system for medication administration is easy for nurses to use, they will gain confidence in their ability to administer medications with the technology and hence be more satisfied with it. Subsequent research has confirmed that both constructs are predictors of acceptance, with usefulness being the stronger predictor. ${ }^{20} 2123105-107$

Box 1 Indicators of top management commitment to a new technology

- Shows end users (nurses, physicians, pharmacists) where responsibility for the different aspects of the changes lie.

- Creates a structured program tailored to promote acceptance and effective use among healthcare providers.

- Designs a training program that is science based and targets the range of perceptions that can affect success.

- Implements well designed pilot testing that will allow for accurate debugging of the technology in the context of use, whether in nursing units, operating rooms, or outpatient clinics.

- Delivers information to end users with the content and in the format that targets the range of perceptions that can affect success.

- Establishes clear lines of communication so that end users know who to go to with problems or suggestions.

- Uses good recommendations from sharp end employees to show them that their ideas are taken seriously.

- Provides a simulation area where end users can practise using the new technology-for example, $\mathrm{CPOE}$ - in a safe environment where mistakes will not lead to patient harm.

- Encourages end user participation in all aspects of the implementation so that they feel more in control and learn early about the technology.
Most of the research on the TAM, however, has examined technologies that could be used voluntarily but, in health care, many implementations result in more mandatory use of new technology. Recent research examining technology acceptance for mandatory technologies has found mixed results. In some cases the original TAM holds ${ }^{51}$ but, in others, ease of use appears to be a better predictor of outcomes than usefulness ${ }^{57}$ while, in yet others, neither perceived ease of use nor usefulness predicted behavioural intentions. ${ }^{108}$ Evidence has also shown that what predicts end user satisfaction or acceptance of a technology changes over time with greater use of the technology. ${ }^{109}$ Regardless of whether usefulness, ease of use, and/or another variable such as self-efficacy are the main determinants of acceptance among mandatory technologies, the same basic implementation design principles will apply, as will be discussed later.

Technology characteristics such as response time, flexibility, breakdowns or crashes, and usability have been proposed to have both direct and indirect effects on technology acceptance. ${ }^{110}$ The direct effect hypothesis suggests that well designed technologies will be more likely to be accepted than those perceived to be poorly designed. The indirect hypothesis proposes that technology changes the nature of work, and end users then react to the changes in work. The indirect hypothesis has received support in the job stress literature, which has shown that new technologies can lead to changes in workload and job control which can then affect stress levels. ${ }^{11-113}$

\section{Job factors}

The degree of job change caused by the implementation of a new technology is also an important issue. Earlier discussions in this paper explained how new technologies may change job structure and therefore influence perceptions of the technology, and there is empirical evidence to confirm the proposition. Specifically, research has found that perceptions of negative impacts on users were found more often when new technology implementations led to greater changes in work structure. ${ }^{114}$ Most patient safety technologies are likely to lead to significant job changes. For example, point of care bar coded medication administration systems have the potential drastically to change the way nurses dispense, administer, and document medications.

\section{Individual factors}

Several individual difference variables have been found to predict technology acceptance. Self-efficacy, as it relates to new technologies, refers to user perceptions that they are confident they can successfully use the new technology. Empirical evidence shows that computer self-efficacy can 
Table 2 Implementation design principles with explanations

\begin{tabular}{ll}
\hline Design principle & Reason for importance \\
\hline $\begin{array}{l}\text { Top management } \\
\text { commitment }\end{array}$ & Enables additional design principles \\
Responsibility/ & \\
accountability & $\begin{array}{l}\text { Effective in promoting success because it } \\
\text { shows the importance of the change and } \\
\text { lets end users know who to go to with ideas } \\
\text { or concerns }\end{array}$ \\
Structured program & $\begin{array}{l}\text { Provides end users with a "road map" } \\
\text { which can reduce uncertainty and promote } \\
\text { feelings of control. It reduces many of the } \\
\text { fears associated with new technology: end } \\
\text { users will know why the change is coming } \\
\text { what to expect, when to expect it, where to } \\
\text { expect it to happen, and who will be in } \\
\text { charge }\end{array}$ \\
$\begin{array}{l}\text { Targets self-efficacy, ease of use, and } \\
\text { usefulness explicitly, but also reduces } \\
\text { uncertainty and fear and promotes control } \\
\text { because users gain knowledge and skills }\end{array}$ \\
$\begin{array}{l}\text { Involves users with the technology and } \\
\text { creates a test bed to uncover and solve } \\
\text { problems. It also promotes an } \\
\text { understanding of integration needs. Pilot } \\
\text { testing should be done in a sufficient }\end{array}$ \\
number of locations so that the results can \\
be applied to the remainder of the facility
\end{tabular}

Feedback Feedback on end user concerns and ideas must be provided quickly so that they know they are being taken seriously. Staffing a help desk accessible in person, by telephone, or over the computer with knowledgeable staff at all times when people are engaged in using the technology is one way to ensure prompt feedback

Simulation

Simulation should be used before, during, and after an implementation. On all three occasions it promotes self-efficacy, usefulness, ease of use, and control while reducing the variety of fears that can exist. Simulation here refers to having the actual technology available to use in the intended manner, but without the possible negative consequences. During and after implementation a simulation room that has the technology operational and allows users to engage the technology without fear of adverse outcomes is important

End user participation

Enhances perceptions of justice, selfefficacy and control, reduces a variety of fears and uncertainty. May have both cognitive and motivational components have an impact on intentions to use computers. ${ }^{6568} 115$ Level of education and previous experience with similar technology has been found to influence perceived ease of use which affects acceptance. ${ }^{107}$ Age has been found to be an important moderator for acceptance and sustained use, with attitudinal factors (for example, effect on performance) being more important for younger workers and social and process variables (for example, ease of use, perceptions of others) being more important for older workers. ${ }^{102}$ Gender has also been found to be a moderator; for women, ease of use and subjective norms are critical while, for men, usefulness is important. ${ }^{104}$ It might seem that, since these factors are beyond the control of the organization, they can be ignored. This is not the case. But that does not mean having to create separate implementation processes for each employee. Implementation processes that follow the design guidelines will, in fact, accommodate the range of needs of men and women, young and old, experts and novices.

\section{DESIGN PRINCIPLES FOR SOUND NEW TECHNOLOGY IMPLEMENTATION PROCESSES}

The research reviewed can be translated directly into design guidelines for implementation processes. Table 1 presents a matrix of guidelines together with the major predictors they affect. The assumption underlying the table is that the design principles presented will only positively affect the predictors of success if they are designed properly. As can be seen, most of the design principles can have a positive impact on most, if not all, of the predictors of acceptance. That does not mean that an organization can simply choose one of the principles that affect all of the predictors. Each of the design principles affects predictors through specific mechanisms so they are all important. Commitment of top management is the most crucial because it enables the resources for implementing each of the other principles (box 1). Table 2 provides a list of the design guidelines together with specific explanations of why each is important.

\section{CONCLUSIONS}

For the foreseeable future, healthcare organizations will face pressures to implement technologies that have the potential to reduce medical errors. While in theory such technologies (such as CPOE) should be able to reduce medical errors, this will only be the case if the technologies are user friendly and designed to help healthcare providers do their jobs better. But even that may not go far enough to promote user satisfaction with, and effective use of, these technologies. Technology implementation processes must also be designed according to

\section{Key messages}

- Designing patient safety technologies such as computerized provider order entry or bar coded medication administration systems to be usable (easy to use) and useful (will improve job performance, efficiency, and/ or quality) is necessary but not sufficient to ensure that the full safety benefits of the technologies can be achieved.

- In addition to usability and usefulness, technology should be implemented according to the science of technology implementation to promote effective technology use (that is, the technology is used in the manner intended) and satisfaction.

- There are a number of specific design principles that can improve the design of technology implementations.

- These include having somebody responsible and accountable for the success of the implementation, conducting pilot testing of the system in a sufficient number of locations so that the results can be applied to the remainder of the facility, and seeking appropriate end user participation in all phases of the implementation. 
scientific principles if the patient safety potential of these technologies is to be realized. Healthcare organizations that ignore implementation design principles increase the risk that users (physicians, nurses, pharmacists) will reject the technologies that could ultimately improve patient safety. Given the high cost of patient safety technologies, healthcare organizations can ill afford to make such mistakes.

Portions of this work were funded by a grant from the US Agency for Healthcare Research and Quality (1 R01 HS013610-01).

\section{REFERENCES}

1 Bates DW. Using information technology to screen for adverse drug events. Am J Health-System Pharmacy 2002;59:2317-9.

2 Bates DW, Evans RS, Murff H, et al. Detecting adverse events using information technology. J Am Med Informatics Assoc 2003;10:115-28.

3 Bates DW, Gawande AA. Patient safety: improving safety with information technology. N Engl J Med 2003;348:2526-34.

4 Institute of Medicine. Crossing the quality chasm: a new health system for the 21 st century. Washington, DC: National Academy Press, 2001.

5 Kaushal R, Barker KN, Bates DW. How can information technology improve patient safety and reduce medication errors in children's health care? Arch Pediatr Adolesc Med 2001;155:1002-7.

6 Kaushal R, Bates DW. Information technology and medication safety: what is the benefit? Qual Saf Health Care 2002;1 1:261-5.

7 Shojania KG, Duncan BW, McDonald KM, Wachter RM, eds. Making health care safer: a critical analysis of patient safety practices. Rockville, MD: Agency for Healthcare Research and Quality, 2001.

8 Kohn LT, Corrigan JM, Donaldson MS, eds. To err is human: building a safer health system. Washington, DC: National Academy Press, 2000.

9 The Leapfrog Group. The Leapfrog Group for patient safety: rewarding higher standards, http://www.leapfroggroup.org (accessed 6 March 2004).

10 Merli R, Stickler M. E-prescriptions promise patient safety, higher drug sales, $\mathrm{http}: / /$ www.kpmginsiders.com/display_analysis.asp?cs_id $=96118$ (accessed 6 March 2004).

11 Institute for Safe Medication Practices. ISMP survey shows drug companies providing fewer unit dose packaged medications (6 March 2002 ISMP Medication Safety Alert). I. http://www.ismp.org/msaarticles/ cuttingprint.htm (accessed 6 March 2004).

12 Nielsen J. Usability engineering. San Francisco: Morgan Kaufmann, 1994

13 Norman DA. The design of everday things. New York: Doubleday, 1988.

14 Gosbee J. Human factors engineering and patient safety. Qual Saf Health Care 2002;11:352-4.

15 Vicente KJ. From patients to politicians: a cognitive engineering view of patient safety. Qual Saf Health Care 2002;11:302-4.

16 Donchin Y. Resuscitation trolleys: human factors engineering. Qual Saf Health Care 2002;11:393.

17 Rogoski RR. Opening the floodgates of usability. Clinical information systems allow free flow of patient data to clinicians when and where they need it. Health Manage Technol 2003;24:12-7.

18 Leong F, Nicholson AG, McGee JO. Robotic telepathology: efficacy and usability in pulmonary pathology. J Pathol 2002;197:21 1-7.

19 Kushniruk A. Evaluation in the design of health information systems: application of approaches emerging from usability engineering. Computers Biol Med 2002;32:141-9.

20 Davis FD. Perceived usefulness, perceived ease of use, and user acceptance of information technology. Mis Quarterly 1989;13:319-40.

21 Davis FD. User acceptance of information technology system characteristics, user perceptions and behavioral impacts. Int I Man-Machine Stud 1993;38:475-87.

22 Venkatesh V. Determinants of perceived ease of use: integrating control, intrinsic motivation, and emotion into the technology acceptance model. Inform Syst Res 2000;11:342-65.

23 Venkatesh V, Speier C, Morris MG. User acceptance enablers in individual decision making about technology: toward an integrated model. Decis Sci 2002;33:297-316

24 Carayon P, Karsh B. Sociotechnical issues in the implementation of imaging technology. Behav Inform Technol 2000;19:247-62.

25 Karsh B. An examination of employee participation during new technology implementation. In: Proceedings of the Human Factors and Ergonomics Society 41st Annual Meeting 1997;2:767-71.

26 Smith MJ, Carayon P. New technology, automation, and work organization: stress problems and improved technology implementation strategies. Int J Human Factors in Manufacturing 1995;5:99-116.

27 Baker LC, Phibbs CS. Managed care, technology adoption, and health care: the adoption of neonatal intensive care. Rand J Econ 2002;33:524-8.

28 Ash JS, Lyman J, Carpenter J, et al. A diffusion of innovations model of physician order entry. J Am Med Informatics Assoc 2001:22-6.

29 Carroll JS, Edmondson AC. Leading organisational learning in health care. Qual Saf Health Care 2002;11:51-6.

30 Chau PYK, Hu PJH. Investigating healthcare professionals' decisions to accept telemedicine technology: an empirical test of competing theories. Information \& Management 2002;39:297-311.

31 Dixon DR, Stewart M. Exploring information technology adoption by family physicians: survey instrument valuation. J Am Med Informatics Assoc 2000:185-9.
32 Edmondson AC, Bohmer RM, Pisano GP. Disrupted routines: team learning and new technology implementation in hospitals. Admin Sci $Q$ 2001;46:685-716.

33 Gagnon MP, Godin G, Gagne C, et al. An adaptation of the theory of interpersonal behaviour to the study of telemedicine adoption by physicians. Int J Med Informatics 2003;71:103-15.

34 Hu PJH, Chau PYK, Sheng ORL. Adoption of telemedicine technology by health care organizations: an exploratory study. J Organizational Computing and Electronic Commerce 2002;12:197-221.

35 Hu PJ, Chau PYK, Sheng ORL, et al. Examining the technology acceptance model using physician acceptance of telemedicine technology. J Manage Inform Syst 1999;16:91-112.

36 Poon EG, Blumenthal D, Jaggi T, et al. Overcoming the barriers to implementing computerized physician order entry systems in US hospitals: perspectives from senior management. J Gen Intern Med 2003;18:214.

37 Eason KD. The process of introducing information technology. Behav Inform Technol 1982;1:197-213.

38 Eason KD. New systems implementation. In: Wilson J, Corlett EN, eds. Evaluation of human work: a practical ergonomic methodology. London Taylor and Francis, 1990:835-49.

39 Eason K. Changing perspectives on the organizational consequences of information technology. Behav Inform Technol 2001;20:323-8.

40 Liker JK, Majchrzak A. Designing the human infrastructure for technology In: Karwowski W, Salvendy G, eds. Organization and management of advanced manufacturing.John Wiley and Sons, 1994:121-63.

41 Mankin D, Bikson T-K, Gutek B-A. Factors in successful implementation of computer-based office information systems: a review of the literature with suggestions for OBM research. J Organ Behav Manage 1984;6:1-20.

42 Korunka C, Huemer KH, Litschauer B, et al. Working with new technologies: hormone excretion as an indicator for sustained arousal. A pilot study. Biol Psychol 1996;42:439-52

43 Liu $M$, Denis $H$, Kolodny $H$, et al. Organization design for technological change. Hum Relations 1990;43:7-22.

44 Hurley J-J. Towards an organisational psychology model for the acceptance and utilisation of new technology in organisations. Ir J Psychol 1992;13:17-31.

45 Joshi K. A model of users' perspective on change: the case of information systems technology implementation. MIS Quarterly 1991;15:229-42.

46 Martinko M-J, Henry J-W, Zmud R-W. An attributional explanation of individual resistance to the introduction of information technologies in the workplace. Behav Inform Technol 1996;15:313-30.

47 Szajna B, Scamell R-W. The effects of information system user expectations on their performance and perceptions. MIS Quarterly 1993;17:493-516.

48 McNutt RA, Abrams R, Aron DC. Patient safety efforts should focus on medical errors. JAMA 2002;287:1997-2001.

49 Layde PM, Cortes LM, Teret SP, et al. Patient safety efforts should focus on medical injuries. JAMA 2002;287:1993-7.

50 Sanders MS, McCormick EJ. Human factors in engineering and design, 7th ed. New York: McGraw-Hill Science, 1993.

51 Venkatesh V, Davis FD. A theoretical extension of the Technology Acceptance Model: four longitudinal field studies. Manage Sci 2000;46:186-204.

52 Ajzen I, Fishbein M. Understanding attitudes and predicting behavior. Englewood Cliffs, NJ: Prentice Hall, 1980.

53 Prochaska JM, Prochaska JO, Levesque DA. A transtheoretical approach to changing organizations. Admin Policy Mental Health 2001 ;28:247-61.

54 Prochaska JO, Velicer WF. The transtheoretical model of health behavior change. Am J Health Promotion 1997;12:38-48.

55 Rogers EM. Diffusion of innovations. 4th ed. New York: The Free Press, 1995.

56 Godin G, Kok G. The theory of planned behavior: a review of its applications to health-related behaviors. Am J Health Promotion 1996;11:87-98.

57 Adamson I, Shine J. Extending the new technology acceptance model to measure the end user information systems satisfaction in a mandatory environment: a bank's treasury. Technol Analysis Strategic Manage 2003;15:441-55

58 Da Villa F, Panizzolo R. Empirical study of the adoption and implementation of advanced technologies in the Italian public sector. Int J Technol Manage 1996;12:181-98.

59 Majchrzak A. Management of technological and organizational change. In: Salvendy G, eds. Handbook of industrial engineering. New York: John Wiley and Sons, 1992:767-97.

60 Hunsucker JL, Loos D. Transition management: an analysis of strategic considerations for effective implementation. Eng Manage Int 1989;5:167-78.

61 Armenakis AA, Harris SG, Mossholder KW. Creating readiness for organizational change. Hum Relations 1993;46:681-703.

62 Cannon-Bowers JA, Salas E, Tannenbaum Sl, et al. Toward theoretically based principles of training effectiveness - a model and initial empirical investigation. Military Psychol 1995;7:141-64.

63 Cannon-Bowers JA, Tannenbaum SI, Salas E, et al. Toward an integration of training theory and technique. Human Factors 1991;33:281-92.

64 Salas E, Cannon-Bowers JA. The science of training: a decade of progress. Annu Rev Psychol 2001;52:471-99.

65 Agarwal R, Sambamurthy V, Stair RM. Research report: the evolving relationship between general and specific computer self-efficacy -an empirical assessment. Inform Syst Res 2000;11:418-30.

66 Venkatesh V. Creation of favorable user perceptions: exploring the role of intrinsic motivation. MIS Quarterly 1999;23:239-60. 
67 Swan J-A. Exploring knowledge and cognitions in decisions about technological innovation: mapping managerial cognitions. Hum Relations 1995;48:1241-70

68 Compeau DR, Higgins CA. Computer self-efficacy: development of a measure and initial test. MIS Quarterly 1995; 19:189-211.

69 Carayon P, Smith MJ. The balance theory of job design and stress as a model for the management of technological change. Paper presented at, Proceedings of the Fourth International Congress of Industrial Engineering France, Marseille, 15-17 December, 1993.

70 Hyclak TJ, Kolchin MG. Worker involvement in implementing new technology. Technovation 1986;4:143-51.

71 Erez M, Gopher D, Arzi N. Effects of goal difficulty, self-set goals, and monetary rewards on dual task performance. Organ Behav Human Decis Proc 1990;47:247-69.

72 Alexander CJ, Schuldt WJ. Effects of choice, goal difficulty, and need achievement on performance. J Clin Psychol 1984;40:1354-61.

73 Mento AJ, Steel RP, Karren RJ. A meta-analytic study of the effects of goal setting on task performance: 1966-1984. Organ Behav Human Decis Proc 1987;39:52-83.

74 Spector PE. Perceived control by employees: a meta-analysis of studies concerning autonomy and participation at work. Human Relations 1986;39:1005-16.

75 Jackson SE. Participation in decision making as a strategy for reducing jobrelated strain. J Appl Psychol 1983:68:3-19.

76 Korunka C, Weiss A, Karetta B. Effects of new technologies with special regard for the implementation process per se. J Organ Behav 1993; 14:331-48.

77 Wagner III JA. Participation's effects on performance and satisfaction: a reconsideration of research evidence. Acad Manage Rev 1994;19:312-30.

78 Wagner III JA, Leana CR, Locke EA, et al. Cognitive and motivational frameworks in US research on participation: a meta-analysis of primary effects. J Organ Behav 1997;18:49-65.

79 Latham GP, Winters DC, Locke EA. Cognitive and motivational effects of participation: a mediator study. J Organ Behav 1994;15:49-63.

80 Melchior M, Berkman LF, Niedhammer I, et al. Social relations and selfreported health: a prospective analysis of the French Gazel cohort. Soc Sci Med 2003;56:1817-20.

81 Munro L, Rodwell J, Harding L. Assessing occupational stress in psychiatric nurses using the full job strain model: the value of social support to nurses. Int J Nurs Stud 1998;35:339-45.

82 Baronas AMK, Louis MR. Restoring a sense of control during implementation - how user involvement leads to system acceptance. MIS Quarterly 1988;12:111-23.

83 Franz C-R, Robey D. Organizational context, user involvement, and the usefulness of information systems. Decis Sci 1986;17:329-56.

84 McKeen JD, Guimaraes T, Wetherbe JC. The relationship between user participation and user satisfaction - an investigation of 4 contingency factors. MIS Quarterly 1994; 18:427-51.

85 Leonard-Barton D, Sinha D-K. Developer-user interaction and user satisfaction in internal technology transfer. Acad Manage $J$ 1993;36:1125-39.

86 Ganster DC, Fusilier MR. Control in the workplace. In: Cary L, Cooper ITR eds. International review of industrial and organizational psychology 1989. Chichester, England: John Wiley \& Sons, 1989:235-80.

87 Harrison EL. The impact of employee involvement on supervisors. National Productivity Review, 1992;Autumn, 447-52.

88 Folger R. Distributive and procedural justice: combined impact of voice and improvement on experienced inequity. J Personality Soc Psychol 1977;35:108-19.

89 Folger R, Cropanzano R. Fairness theory: justice as accountability. In: Greenberg J, Cropanzano R, eds. Advances in organization justice. Palo Alto, CA: Stanford University Press, 2001:1-55.

90 Cobb AT, Wooten KC, Folger R. Justice in the making: toward understanding the theory and practice of justice in organizational change and development. Research in organizational change and development. Volume 8. Greenwich, CT: JAI Press, 1995:243-95.

91 Cropanzano R, Randall ML. Injustice and work behavior: a historical review. In: Cropanzano R, eds. Justice in the workplace: approaching fairness in human resource management. Hillsdale, NJ: Lawrence Erlbaum Associates, 1993:3-20.

92 Brockner J, Konovsky M, Cooperschneider R, et al. Interactive effects of procedural justice and outcome negativity on victims and survivors of job loss. Acad Manage J 1994;37:397-409.
93 Lowe RH, Vodanovich SJ. A field study of distributive and procedural justice as predictors of satisfaction and organizational commitment. J Business Psychol 1995; 10:99-114.

94 Novelli L, Kirkman BL, Shapiro DL. Effective implementation of organizational change: an organizational justice perspective. In: Cooper C, Rousseau D, eds. Trends in organizational behavior.Volume 2. San Francisco: Jossey-Bass, 1995: 15-36.

95 Greenberg J. The social side of fairness: interpersonal and informational classes of organizational justice. In: Cropanzano R, eds. Justice in the workplace: approaching fairness in human resource management. Hillsdale, NJ: Lawrence Erlbaum Associates, 1993:79-103.

96 Joshi K. An investigation of equity as a determinant of user information satisfaction. Decis Sci 1990;21:786-807.

97 Daly JP, Geyer PD. The role of fairness in implementing large-scale change: employee evaluations of process and outcome in seven facility relocations. J Organ Behav 1994;15:623-38.

98 Brockner J, Dewitt Rl, Grover S, et al. When it is especially important to explain why-factors affecting the relationship between managers explanations of a layoff and survivors reactions to the layoff. J Exp Soc Psychol 1990;26:389-407.

99 Hunton JE, Price KH. Effects of the user participation process and task meaningfulness on key information system outcomes. Manage $\mathrm{Sci}$ 1997; 43:797-812

100 Davis FD, Bagozzi RP, Warshaw PR. User acceptance of computer technology a comparison of two theoretical models. Manage Sci 1989;35:982-1003.

101 Davis S, Wiedenbeck S. The mediating effects of intrinsic motivation, ease of use and usefulness perceptions on performance in first-time and subsequent computer users. Interacting With Computers 2001;13:549-80.

102 Morris MG, Venkatesh V. Age differences in technology adoption decisions: Implications for a changing work force. Personnel Psychol 2000:53:375-403

103 Venkatesh V, Morris MG, Ackerman PL. A longitudinal field investigation of gender differences in individual technology adoption decision-making processes. Organ Behav Hum Decis Processes 2000;83:33-60.

104 Venkatesh V, Morris MG. Why don't men ever stop to ask for directions? Gender, social influence, and their role in technology acceptance and usage behavior. MIS Quarterly 2000;24:115-39.

105 Adams DA, Nelson RR, Todd PA. Perceived usefulness, ease of use, and usage of information technology-a replication. MIS Quarterly 1992; 16:227-47.

106 Taylor S, Todd P. Assessing IT usage: the role of prior experience. MIS Quarterly 1995; 19:561-70.

107 Agarwal R, Prasad J. Are individual differences germane to the acceptance of new information technologies? Decis Sci 1999;30:361-91.

108 Brown SA, Massey AP, Montoya-Weiss MM, et al. Do I really have to? User acceptance of mandated technology. Eur J Inform Syst 2002; 1 1:283-95.

109 Karahanna E, Straub DW, Chervany NL. Information technology adoption across time: a cross-sectional comparison of pre-adoption and postadoption beliefs. MIS Quarterly 1999;23:183-213.

110 Karsh B. The implementation of new technology: a case study in a government agency Masters Thesis. Madison: University of WisconsinMadison, 1996.

111 Korunka C, Zauchner S, Weiss A. New information technologies, job profiles, and external workload as predictors of subjectively experienced stress and dissatisfaction at work. Int J Human-Computer Interact 1997:9:407-24.

112 Carayon P. A longitudinal study of job design and worker strain: preliminary results. In: Quick JC, eds. Stress and well-being at work: assessments and interventions for occupational mental health. Washington, DC: American Psychological Association, 1992:19-32.

113 Asakura T, Fujigaki Y. The impact of computer technology on job characteristics and worker health. In: Smith MJ, Salvendy G, eds. Human computer interaction:applications and case studies. Volume 19A. New York: Elsevier, 1993:982-7.

114 Korunka C, Weiss A, Zauchner S. An interview study of 'continuous' implementations of information technology. Behav Inform Technol 1997;16:3-16.

115 Hill T, Smith N-D, Mann M-F. Role of efficacy expectations in predicting the decision to use advanced technologies: the case of computers. J Appl Psychol 1987;72:307-13. 